\title{
Manajemen Pemasaran Pondok Pesantren Berbasis Program Pengabdian Masyarakat
}

\author{
Iwan Sopwandin \\ Universitas Islam Negeri Sunan Gunung Djati Bandung \\ e-mail: iwansopwandin8@gmail.com
}

\begin{abstract}
This study aims to describe the marketing management of Al-Fadlliyah Islamic boarding school. Marketing at this pesantren focuses on a cooperative approach and community service, so that not only the pesantren cottage benefits, but the community also benefits from the activity. This research method uses qualitative research with case study research type. Data collection techniques used are: interview, observation and documentation. The results show that: 1) the marketing management process at this boarding school is through 4 stages, namely: planning, implementing, monitoring and evaluating; 2) Implications of marketing management of Islamic boarding schools, namely: a) Islamic boarding schools have a good image in the community, b) an increase in the number of students, especially from regions originating from locations where PPM is conducted.
\end{abstract}

Keyword. Marketing; Islamic Boarding School; Community Service

Abstrak. Penelitian ini bertujuan mendeskripsikan manajemen pemasaran pondok pesantren Al-Fadlliyah. Pemasaran di pesantren ini berfokus pada pendekatan kerjasama dan pengabdian pada masyarakat, sehingga bukan hanya pondok pesantren yang diuntungkan, tetapi masyarakat juga mendapatkan manfaat dari kegiatan tersebut. Metode penelitian ini menggunakan penelitian kualitatif dengan jenis penelitian studi kasus. Tehnik pengumpulan data yang digunakan yaitu: teknik wawancara, observasi dan dokumentasi. Hasilnya menunjukan bahwa: 1) proses manajemen pemasaran dipondok pesantren ini melalui 4 tahapan, yaitu: perencanaan, pelaksanaan, pemantauan dan evaluasi; 2) Implikasi manajemen pemasaran pondok pesantren, yaitu: a) Pondok pesantren memiliki citra yang baik dimasyarakat, b) adanya kenaikan jumlah santri khususnya dari daerah yang berasal dari lokasi tempat PPM dilaksanakan.

Kata Kunci. Pemasaran; Pesantren; Pengabdian Masyarakat

Copyright @ JMPI: Jurnal Manajemen Pendidikan Islam. All Right Reserved.

This is an open access article under the CC BY-NC-ND license

(http://creativecommons.org/licenses/by-nc-nd/4.0/).

\section{A. PENDAHULUAN}

Seiring berjalannya waktu, pondok pesantren hari ini sedang mengalami kepercayaan diri yang sangat tinggi. Hal tersebut terlihat dari semakin bertambahnya kepercayaan masyarakat menitipkan anak-anaknya kepada pesantren. Hal ini setidaknya bisa dilihat dari peningkatan jumlah pondok pesantren di Indonesia. Data Kementerian Agama tahun 2015 misalnya, menunjukkan jumlah pesantren yang tercatat di Kementerian Agama sebanyak 25.785. Jumlah ini jauh meningkat dibanding data 1997, yang tercatat baru sebanyak 4.196 buah (Muadin, 2017).

Pesantren merupakan lembaga pendidikan atau sekolah Islam tertua di indonesia dan termasuk salah satu dari 3 tipe sekolah Islam di indonesia. Maintaining their status as private educational institutions, pesantrens are the bastion of Islamic knowledge and the main provider of Islamic scholars and teachers. They focus on the transmission of the classical Islamic

Vol. 4 No. 2, Desember 2019

J-MPI homepage: http://ejournal.uin-malang.ac.id/index.php/jmpi/index 
sciences, including the study of the Qur'an and hadith, jurisprudence, Arabic grammar, mysticism (tasawwuf), and the Arab sciences (alat) (Tan, 2011).

Menurut pandangan Azra, Pesantren di Indonesia berbeda dengan Negara di Timur Tengah. Hal tersebut dapat dilihat dari sikap lembaga pendidikan tradisional pesantren yang menerima sistem dan tuntutan perkembangan zaman. Sebagaimana pendidikan di lingkungan pesantren sendiri yang mengadopsi sistem pendidikan umum seperti SMA, SMK tanpa meninggalkan tradisinya seperti pengajian atau materi belajar bersumber pada kitab kuning yang merupakan ciri khas pesantren sejak awal berdirinya. Berbeda dengan apa yang terjadi di Turki Usmani, sistem pendidikan di Negara tersebut pada mulanya tidak menjadikan madrasah sebagai lembaga pendidikan tradisional Islam sehingga tidak menjadi sasaran pembaharuan (Heriyudanta, 2016). Sehingga dengan begitu pesantren di setiap negara dan memiliki perbedaan baik itu dari sistemnya, pola pembelajarannya, dll. Bahkan di indonesia sekalipun, contohnya dari dan tradisinya, pesantren di indonesia ada tradisional dan pesantren modern (Muhakamarurohman, 2014).

Di era teknologi ini, semakin banyak bermunculan pesantren-pesantren modern, sehingga untuk menjaga pesantren yang sudah lama berdiri diperlukan strategi untuk menarik minat masyarakat, yaitu dengan melakukan pemasaran baik itu menggunakan media sosial ataupun sistem manual, yang terpenting intinya hal tersebut merupakan bagian dari manajemen pemasaran. Tentunya peningkatan tersebut adalah buah hasil kerja keras semua kalangan, baik itu pihak pesantren, masyarakat dan pemerintah. puncaknya beberapa tahun terakhir ini berbagai kegiatan pesantren menjadi perhatian dan menarik simpati hampir seluruh masyarakat indonesia, salah satunya pada bulan November 2018 pemerintah meluncurkan Beasiswa lembaga pengelola dana pendidikan (Lpdp) untuk santri, meskipun beasiswa dari tahun-tahun sebelumnya sudah ada, karena beasiswa ini merupakan beasiswa yang bisa dibilang bergensi dan banyak diminati oleh kaum intelek yang ingin melanjutkan pendidikan.

Pesantren menjadi salah satu solusi bagi masyarakat untuk melindungi anakanaknya dari pergaulan dan lingkungan yang hari ini juga sangat memprihatinkan, dan juga untuk mengurangi penggunaan media elektronik yang tidak bermanfaat dan belum dibutuhkan oleh anak-anak. Kekhasan pesantren juga menjadi salah satu daya tarik masyarakat baik itu untuk orang tua atapun anaknya. Sebab, dipesantren juga santri memiliki komunitas belajar yang sangat banyak, tidak hanya belajar pengetahuan, tetapi juga santri belajar bekerjasama serta hidup bersama dan ini menjadi salah satu bekal bermasyarakat.

Pada mulanya pesantren masih dipandang sebelah mata, salah satu contohnya yaitu ketika dulu pada awal perkembangannya pada periode Orde Baru, seakan tenggelam eksistensinya karena seiring dengan kebijakan pemerintah yang kurang berpihak pada kepentingan ummat Islam, dan baru ada harapan pada era reformasi, yaitu pondok pesantren menjadi bagian dari sistem pendidikan nasional yang termaktub dalam Undang-Undang Sistem Pendidikan Nasional (Sisdiknas) (Pontren, n.d.), selanjutnya juga image pesantren dimasyarakat itu lembaga yang kumuh, jorok dan konservatif. Tetapi hari ini pandangan tersebut sudah mulai beralih ke pandangan bahwa pesantren merupakan lembaga pendidikan yang bisa membentuk dan menjadikan santri yang tidak hanya kokoh keyakinan keagamaannya, tetapi juga memiliki kemampuan intelektual dan melek tehnologi, karena pembelajaran di

Vol. 4 No. 2, Desember 2019

J-MPI homepage: http://ejournal.uin-malang.ac.id/index.php/jmpi/index 
pesantren saat ini tidak hanya belajar kitab-kitab saja, tetapi ada inovasi yang itu disesuaikan dengan perkembangan zaman sekarang, baik itu metode dan sistem pembelajarannya, bangunannya yang modern, penambahan program-program pesantren seperti wirausaha, pelatihan komputer atapun soft skill yang lainnya. Apalagi setelah adanya penyetaraan pendidikan pesantren dengan sekolah pada umumnya.

Di sadari atau tidak, secara tidak langsung hal tersebut merupakan strategi untuk menarik perhatian masyarakat, hal tersebut merupakan bagian manajemen pemasaran pesantren. Seiring pesatnya kemunculan pesantren-pesantren modern yang fasilitasnya juga modern, maupun sistemnya yang modern, untuk tetap menjaga eksistensi pesantren, terutama salafi yang bisa dibilang fasilitasnya masih terbatas dan lokasinya yang terbilang pelosok atau jauh dari pusat kota, tentunya pemasaran yang termanaj tersebut sangat diperlukan.

Manajemen Pemasaran adalah proses perencanaan dan pelaksanaan, pemikiran, penetapan harga promosi, serta penyaluran gagasan barang, dan jasa untuk menciptakan pertukaran yang memenuhi sasaran-sasaran individu dalam organisasi (Kotler, 2016). Sedangkan menurut Walker dan Larroche, pemasaran adalah suatu proses sosial yang melibatkan kegiatan-kegiatan penting yang memungkinkan individu dan perusahaan mendapatkan apa yang mereka butuhkan dan inginkan melalui pertukaran dengan pihak lain dan untuk mengembangkan hubungan pertukaran (Boyd, 2000). Pemasaran untuk lembaga pendidikan termasuk pesantren mutlak dilakukan (Ainul Yaqin, 2016).

Pendidikan yang didalamnya salah satunya pesantren termasuk kedalam lembaga yang produk pemasarannya adalah jasa. Kata jasa mempunyai banyak arti dan ruang lingkup, dari pengertian yang paling sederhana, yaitu hanya berupa pelayanan dari seseorang kepada orang lain, bisa juga diartikan sebagai mulai dari pelayanan yang diberikan oleh manusia, baik yang dapat dilihat (explicit service), yang bisa dirasakan (implicit service) sampai pada fasilitasfasilitas pendukung yang harus tersedia dalam penjualan jasa dan benda-benda lainnya (Jasfar, 2005). Proses pemasaran salah satunya tercipta dari kegiatan promosi. Promosi dipandang sebagai arus informasi atau persuasi satu arah yang dibuat untuk mengarahkan seseorang atau organisasi kepada tindakan yang menciptakan pertukaran dan pemasaran (Karim, Mulyani, Boga, \& Balikpapan, 2015).

Setiap pesantren memiliki strategi pemasaran yang berbeda-beda. Pemasaran jasa pendidikan dalam hal ini pondok pesantren dapat direalisasikan dengan mengoptimalkan beberapa sumber saluran sejumlah media baik itu media cetak maupun media elektronik (langsung dan tidak langsung) (Sarifudin, 2018). Berbeda dengan Pondok Pesantren Al-Fadlliyah, bentuk pemasaran tersebut terbilang cukup unik, yaitu dengan terjun langsung terjun ke masyarakat, sehingga disini terjadi simbiosis mutualisme, saling menguntungkan antara masyarakat dan pihak pondok pesantren, kegiatan tersebut dinamakan Program Pengabdian Masyarakat.

\section{B. METODE}

Penelitian ini menggunakan pendekatan kualitatif dengan metode deskriptif dan dengan jenis penelitian studi kasus. Teknik pengumpulan data yang digunakan yaitu: teknik observasi, wawancara dan dokumentasi.

Teknik observasi merupakan aktivitas peneliti yang langsung turun ke lapangan untuk mengamati perilaku dan aktivitas individu-individu di lokasi penelitian 
(Creswell, 2013). Teknik ini juga dilakukan dengan melakukan pengamatan secara intensif serta mendengarkan secermat mungkin sampai kepada hal yang sekecilkecilnya. Selama berada di lokasi, Teknik ini bertujuan untuk mengumpulkan data sebanyak-banyaknya tentang kondisi objektif, letak geografis lokasi pelaksanaan PPM, dan proses pelaksanaan kegiatan PPM.

Teknik wawancara adalah teknik pengumpulan data apabila peneliti ingin melakukan studi pendahuluan untuk menemukan permasalahan yang harus diteliti, tetapi juga apabila peneliti ingin mengetahui hal-hal dari responden yang lebih mendalam (Sugiyono, 2014). Dalam penelitian ini wawancara digunakan untuk mengetahui secara lebih mendalam tentang Proses Manajemen pemasaran melalui PPM.

Teknik ini dilakukan dengan terlebih dahulu menentukan key informant, dalam hal ini Pimpinan Pondok Pesantren Al-Fadlliyah. Yang akan di wawancara dalam penelitian ini adalah:

a) Pimpinan pondok pesantren Al-Fadlliyah, untuk mendapatkan data tentang: (1) Sejarah Manajemen Pemasaran melalui PPM, (2) Proses Manajemen Pemasaran pesantren melalui PPM.

b) Koordinator lapangan, untuk mendapatkan data tentang: (1) Proses pelaksanaan Pemasaran, (2) Proses Manajemen Pemasaran Melalui PPM.

c) Pembimbing lapangan, untuk mendapatkan data tentang proses PPM.

d) Masyarakat, untuk mendapatkan data mengenai manfaat yang dirasakan dari kegiatan PPM tersebut.

Teknik Dokumen merupakan pengambilan data berupa dokumen publik (seperti, Koran, makalah ataupun laporan kantor) ataupun dokumen privat (seperti, buku harian,, diary, surat, email). Dalam hal ini salah satu dokumen yang didapatkan yaitu: Dokumentasi kegiatan PPM dan buku panduan PPM.

\section{HASIL DAN PEMBAHASAN}

Pengelolaan Pemasaran Pondok Pesantren Berbasis Program Pengabdian Masyarakat

Sama halnya dengan manajemen pemasaran pesantren pada umumnya, pemasaran ini bertujuan untuk memperkenalkan produk atau lembaga tersebut kepada masyarakat, dengan tujuan mendapatkan laba atau keuntungan, dalam hal ini yaitu penambahan santriwan dan santriwati baru (Mustaqim, 2018). Tentunya yang dilakukan di pondok pesantren Al-Fadlliyah ini juga sama, hanya saja cara yang dipakai adalah dengan terjun bergabung di masyarakat yang disebut dengan program pengabdian masyarakat (PPM), selama kurang lebih 10 hari.

Strategi pemasaran ini sudah berjalan dari tahun 2014 sampai sekarang, kegiatan ini berlangsung setiap tahun yaitu di sela-sela libur semester ganjil pesantren dan sekolah. Yang menjadi peserta PPMnya yaitu santri dan santriah kelas 6 Pondok Pesantren Al-Fadlliyah dan dampaknya sangat positif baik itu secara citra maupun adanya peningkatan jumlah santri yang mondok terutama dari daerah yang dilaksanakan kegiatan tersebut.

Manajemen pemasaran pondok melibatkan pimpinan pondok pesantren hingga santri-santriah, tentunya dengan bidang/bagian yang berbeda-beda. Manajemen pemasaran pondok pesantren ini melalui 4 tahap, yaitu: perencanaan, pelaksanaan pemantauan dan evaluasi (Bachtiar, 2018).

1. Tahap Perencanaan

Vol. 4 No. 2, Desember 2019

J-MPI homepage: http://ejournal.uin-malang.ac.id/index.php/jmpi/index 
Perencanaan disini juga meliputi persiapan. Persiapan terdiri dari beberapa kegiatan, yaitu: a) sosialisasi pelaksanaan PPM oleh koordinator pelaksana kepada peserta PPM, dalam hal ini kelas 6 pondok pesantren; b) penentuan lokasi PPM, pada tahap ini terlebih dahulu pihak pesantren menyurvey beberapa lokasi yang akan dijadikan lokasi PPM. Setelah ditetapkan berdasarkan kriteria yang ada, maka pesantren melalui koordinator pelaksana membuat kesepakatan dengan pemerintah setempat, sehingga kegiatan PPM legal dan mendapat persetujuan dari pemerintah disana; c) Izin Lokasi PPM, setelah adanya kesepakatan dengan apartur pemerintahan desa, selanjutnya koordinator dan pembimbing meminta izin kepada rukun warga (RW) dan tokoh dilokasi tersebut, karena pelaksanaan PPM tempatkan di tiap RW yang ada didesa tersebut; d) pembentukan kelompok PPM, sesuai dengan jumlah RW yang akan dijadikan lokasi PPM; e) pembekalan peserta PPM, kegiatan ini bertujuan untuk memberikan arahan dan informasi mengenai kegiataan PPM serta pemberian nasihat oleh dewan ustadz yang ada dipesantren; f) observasi, kegiatan ini dilakukan oleh koordinator pelaksana, pembimbing dan ketua dari masing-masing kelompok PPM, yang bertujuan untuk mengenal sekilas mengenai kondisi dan keadaan masyarakat disana sekaligus mencari rumah yang akan digunakan oleh peserta PPM.

Pada intinya proses pertama ini yaitu pemantapan tempat dan peserta PPM, dalam bauran pemasaran kedua unsur tersebut merupakan Place and Product pemasaran. Place/tempat merupakan lokasi pemasaran tersebut dilaksanakan, sedangkan Produk merupakan hal yang paling mendasar yang akan menjadi pertimbangan preferensi pilihan bagi customer (Muadin, 2017).

\section{Tahap Pelaksanaan}

Pelaksanaan ini didalamnya juga terdapat proses penggerakan. Penggerakan merupakan rangkaian kegiatan yang dilakukan sesuai perencanaan untuk mencapai sasaran tertentu secara efektif dan efisien (Sopwandin, Nurmila, \& Hidayat, 2019). Tahap pelaksanaan ini terdiri dari beberapa kegiatan, yaitu: a) pelepasan peserta PPM yang dilaksanakan oleh pihak pesantren pada malam sebelum keberangkatan esok harinya; $b$ ) pembukaan dan serah terima peserta PPM dari pesantren dalam hal ini diwakili oleh koordinator pelaksana kepada aparatur pemerintahan di kantor desa setempat; c) serah terima peserta di lokasi PPM yang dilakukan oleh pembimbing kepada ketua RW atau Tokoh masyarakat; d) kegiatan PPM.

Kegiatan PPM terdiri dari tiga siklus, yaitu: 1) sosialisasi awal dan rembug warga, dilaksanakan pada waktu yang telah disepakati oleh peserta dan masyarakat setempat, yang didalamnya memaparkan peserta PPM berasal dan tujuan adanya kegiatan PPM ini serta program-program yang akan dilakanakan peserta dilokasi tersebut 2) implementasi program yang telah dipaparkan; 3)penutupan, tahap ini meliputi kegiatan acara perlombaan ciri khas pesantren yang telah diajarkan peserta pada masyarakat yang diakhiri dengan acara perpisahan dan serah terima kembali dari aparatur desa kepada pihak pesantren.

Tahap pelaksanaan menurut Nisa', (2017) merupakan inti dari kegiatan pemasaran ini, dimana pada proses tersebut berlangsung kegiatan pengabdian di masyarakat, dan prosesnya pelaksanaannya berhasil, dikatakan berhasil karena telah mencapai tujuan sebagai berikut:

Vol. 4 No. 2, Desember 2019

J-MPI homepage: http://ejournal.uin-malang.ac.id/index.php/jmpi/index 
1. Menyebarkan informasi mengenai pesantren kepada masyarakat sebagai target pasar potensial.

2. Untuk mendapatkan kenaikan santriwan dan santriwati baru.

3. Membedakan dan mengunggulkan pesantren Al-Fadlliyah dengan pesantren lain.

4. Membentuk citra pesantren dimata masyarakat sesuai dengan yang diinginkan.

Tabel 1. Program-program dalam kegiatan PPM

\begin{tabular}{|c|c|c|c|}
\hline No & Materi & Metode & Sasaran \\
\hline 1 & $\begin{array}{c}\text { Mufrodat Bahasa Arab dan } \\
\text { Kosakata Bahasa Inggris }\end{array}$ & & Anak-anak \\
\hline 2 & Shalawat & & $\begin{array}{c}\text { Anak-anak dan } \\
\text { Ibu-ibu }\end{array}$ \\
\hline 3 & Nadoman & $\begin{array}{c}\text { Anak-anak dan } \\
\text { Ibu-ibu }\end{array}$ \\
\hline 4 & Asmaul Husna & Anak-anak \\
\hline 5 & Pidato bahasa Arab dan Inggris & & Anak-anak \\
\hline 6 & Pembelajaran AL-Qur'an & $\begin{array}{c}\text { Tajwid (MRO), Murotal } \\
\text { (Metode Ummi) }\end{array}$ & Anak-anak \\
\hline 7 & Pengembangan diri (Beladiri) & & Umum \\
\hline 8 & Fiqih Praktis (Wudhu, Shalat) & & Anak-anak \\
\hline 9 & Senam & & Anak-anak \\
\hline
\end{tabular}

Sumber: (Bachtiar, 2018)

\section{Tahap Pemantauan dan Pengawasan}

Pemantauan bertujuan untuk mengamati secara seksama keadaan dan kegiatan yang dilaksanakan oleh peserta PPM. Tahap ini dilakukan oleh pembimbing kelompok, koordinator pelaksana dan pengurus pesantren pada waktu-waktu tertentu. Peserta PPM juga dibekali dengan buku agenda harian peserta PPM. Buku tersebut akan sangat dibutuhkan peserta untuk menyusun laporan PPMnya.

Tabel 2. Form agenda harian

\begin{tabular}{|c|c|c|l|l|c|}
\hline No & Hari ke & Waktu & Kegiatan/Program & Tempat & PJ \\
\hline & & & & & \\
\hline & & & & & \\
\hline & & & & & \\
\hline & & & & & \\
\hline
\end{tabular}

Sumber: (Bachtiar, 2018)

Tahapan ini sudah berjalan sangat baik, karena pemantauan bukan hanya pada form isian saja, tetapi pihak pesantren, koordinator pelaksana dan pembimbing kelompok sering melakukan pemantauan, baik ada pemberitahuan dulu diawal atau langsung datang pada setiap kelompok PPM ketika dengan melakukan kegiatan pengabdian atau juga diwaktu-waktu senggang (Hasil wawancara dengan koordintaor pelaksana PPM). Dalam hal ini, yang mengawasi kegiatan PPM disebut sebagai penilik, dan secara tugas sudah sesuai dan terlaksana dengan baik (Slameto, 2016).

Vol. 4 No. 2, Desember 2019

J-MPI homepage: http://ejournal.uin-malang.ac.id/index.php/jmpi/index 


\section{Evaluasi}

Evaluasi meliputi dua cara, yaitu: 1) peserta PPM menyerahkan laporan akhir kepada koordinator pelaksana, yang selanjutnya diserahkan kepada pihak pesantren. 2) pimpinan pesantren mengevaluasi kegiatan PPM ini melalui seberapa banyak santri yang mendaftar pada ajaran baru dari lokasi yang dijadikan tempat PPM, bila memperlihatkan hal positif, maka kegiatan tersebut akan dilaksanakan kembali pada tahun berikutnya, keputusan yang diambil oleh pimpinan pesantren Al-Fadlliyah sesuai dengan yang dikemukakan Wirawan (2011:7), bahwa: evaluasi sebagai riset untuk mengumpulkan, menganalisis, dan menyajikan informasi yang bermanfaat mengenai objek evaluasi, menilainya dan membandingkannya dengan indikator evaluasi dan hasilnya dipergunakan untuk mengambil keputusan mengenai objek evaluasi (Munthe, 2015).

\section{Implikasi Pengelolaan Pemasaran Pondok Pesantren}

Kegiatan PPM menunjukan hal positif, dari citra pondok pesantren yang semakin baik di mata masyarakat, santri dan santriah pun mengalami peningkatan terutama dari lokasi yang telah dijadikan PPM. Dengan hal itu juga kegiatan PPM tersebut telah berjalan 4 tahun, dari tahun 2014 hingga 2019 ini (Hasil wawancara dengan Pimpinan pondok pesantren Al-Fadlliyah).

\section{KESIMPULAN}

Manajemen pemasaran di pondok pesantren Al-Fadlliyah dilakukan melalui PPM. Proses Manajamen PPM melalui 4 tahapan, yaitu perencanaan, pelaksanaan, pemantauan dan evaluasi. PPM merupakan bentuk kegiatan pemasaran yang sangat efektif, karena dampak yang dirasakan bukan hanya pihak pondok pesantren saja, tetapi masyarakat juga diuntungkan dengan adanya kegiatan PPM tersebut, sehingga hal ini dikatakan sebagai simbosis mutualisme, dimana manfaat yang dirasakan bukan hanya oleh satu pihak melainkan oleh keduanya.

\section{REFERENSI}

Ainul Yaqin, A. (2016). Strategi Pemasaran Pendidikan Di Madrasah Aliyah Unggulan Pondok Pesantren Amanatul Ummah Surabaya. Jurnal Inspirasi Manajemen Pendidikan, 4(1), 1-11.

Bachtiar, Y. (2018). Panduan Program Pengabdian Masyarakat (PPM). Tasikmalaya.

Boyd, W. dan L. (2000). Manajemen Pemasaran: Suatu Pendekatan Strategis dengan Orientasi Global (Edisi Kedu). Jakarta: Erlangga.

Creswell, J. (2013). Research Design: pendekatan kualitatif, kuantitatif dan mixed. Yogyakarta: Pustaka setia.

Heriyudanta, M. (2016). Modernisasi Pendidikan Pesantren Perspektif Azyumardi Azra. Mudarrisa, Jurnal Kajian Pendidikan Islam, 6(1).

Jasfar, F. (2005). Manajemen Jasa: Pendekatan Terpadu. Bogor: Ghalia.

Karim, S., Mulyani, Y., Boga, J. T., \& Balikpapan, P. N. (2015). Evaluasi Kegiatan Promosi Politeknik Negeri. Jurnal Sains Terapan, 2(2).

Kotler, K. (2016). Marketing management. United State America: Pearson Custer Publishing. 
Muadin, A. (2017). Manajemen Pemasaran Pendidikan Pondok Pesantren Tahfidz Qur'an. Ta'allum: Jurnal Pendidikan Islam, 5(2), 293-308. https:/ / doi.org/10.21274/taalum.2017.5.2.293-308

Muhakamarurohman, A. (2014). Pesantren: Santri, Kiai, dan Tradisi. Ibda: Jurnal Kebudayaan Islam, 12(2), 112.

Munthe, A. P. (2015). Pentingnya Evaluasi Program di Institusi Pendidikan. Jurnal Scholaria, 5(2), 1-14.

Mustaqim, M. (2018). Analisis Manajemen Pemasaran Jasa Lembaga Pendidikan Islam: Pondok Pesantren Amtsilati Darul Falah Bangsri Jepara. Jurnal Nadwa, 12(1), 117. https:/ / doi.org/10.21580/nw.2018.12.1.2465

Nisa', K. (2017). Strategi Pemasaran Pondok Pesantren Nurul 'ulum Kauman Kota Gajah Lampung Tengah. Universitas Islam Negeri Raden Intan lampung.

Pontren, D. pendidikan diniyah dan. (n.d.). Sejarah.

Sarifudin. (2018). Implementasi Manajemen Pemasaran Jasa Pendidikan Dalam Meningkatkan Kepuasan Pelanggan Di Madrasah Aliyah Terpadu (Mat) Darul Fallah Bogor. Islamic Management: Jurnal Manajemen Pendidikan Islam, I(2), 257-270. https://doi.org/10.30868/im.v2i02.513

Slameto, S. (2016). Supervisi Pendidikan Oleh Pengawas Sekolah. Kelola: Jurnal Manajemen Pendidikan, 3(2), 192. https:/ / doi.org/10.24246/j.jk.2016.v3.i2.p192-206

Sopwandin, I., Nurmila, N., \& Hidayat, W. (2019). Fungsi-Fungsi Manajemen Di Perpustakaan Madrasah. MADRASA: Journal of Islamic Educational Management, 2(1), 23-32.

Sugiyono. (2014). Metodologi Penelitian Pendidikan Kuantitatif Kualitatif dan RED. Bandung: Alfabeta.

Tan, C. (2011). Islamic education and indoctrination: the case in Indonesia. New york: Routledge. 